\title{
THE USE OF INFORMATION TECHNOLOGIES AT THE STATE AND LOCAL LEVELS
}

\author{
Oksana Zelinska' ${ }^{1}$, Ludmila Volontyr ${ }^{2}$
}

\begin{abstract}
Now, the cause of inefficient management in many enterprises of Ukraine is the insufficient use of information technology. Despite the active support of the sector by the state, the problems of studying and speeding up information flows, development and implementation of information and software systems for automation of management, lack of vision of the prospect IT implementation in managers and, as a consequence, reduction of management mobility, etc. are not fully resolved. The effectiveness of managing the settlement territories depends to a great extent on the completeness and reliability of the initial information used in making decisions on its strategic and operational development. The required information is measured by thousands of indicators that characterize the quantitative and qualitative state of the elements of the environment of the settlement and is collected, accumulated and processed by various branch bodies of state and local authorities. Using e-government tools will provide a significant improvement in service quality individuals and legal entities and increasing openness, transparency and efficiency of the activity of state and local self-government bodies. In addition, the introduction of e-government is a basic prerequisite for building an efficient digital economy and digital market in Ukraine. It is the generalization of electronic registers that will make it possible to make an effective management decision. The purpose of the scientific article is to identify the directions, mechanisms for improving the efficiency of management and control, case study and the influence of the information and communication technologies use on the management systems at the state and local levels. Methodology. The study of the subject area, theoretical foundations of information technology in the management of Vinnytsia areas of improvement; identifying tools and methods for implementing information systems in greening management. The subject of the study is the impact of information technology on improving the effectiveness of control and management decisions. Based on the analysis of information and communication technologies in management local authorities and experience of foreign countries in the area of urban improvement, areas of research to improve management and control are identified. Result of the research. It is determined that the use of information technologies in public administration contributes to the formation of an open democratic society, which will guarantee the observance of the constitutional rights of citizens, to participate in public life, to make appropriate decisions by public authorities and local self-government bodies. The use of e-government tools will significantly improve the quality of service for individuals and legal entities and increase the openness, transparency and efficiency of the activity of public authorities and local self-government bodies.
\end{abstract}

Key words: information technology, management decisions, public administration, optimization, e-government, municipal improvement, landscaping.

JEL Classification: O30, L86

\section{Introduction}

Based on the analysis of information and communication technologies in the management of local authorities and the experience of foreign countries in the field of municipal improvement, it is necessary to determine the areas of research on the efficiency of management and control improvement. The use of information

\footnotetext{
Corresponding author:

${ }^{1}$ Vinnytsia National Agrarian University, Ukraine.

E-mail: zeloksanav.lad@gmail.com

ORCID: https://orcid.org/0000-0002-9069-1428

ResearcherID: I-5420-2018

${ }^{2}$ Vinnytsia National Agrarian University, Ukraine.

E-mail:vm@vsau.vin.ua

ORCID: https://orcid.org/0000-0001-9022-9332

ResearcherID: L-8944-2018
} 
technologies in public administration contributes to the formation of an open democratic society, which will guarantee upholding of citizens' constitutional rights concerning their participation in public life, making appropriate decisions by public authorities and local selfgovernment bodies.

The use of e-government tools will significantly improve the quality of service to individuals and legal entities and to increase the openness, transparency and efficiency of the activity of state and local self-government bodies. Also, the introduction of e-governance is a basic prerequisite for building an efficient digital economy and digital market in Ukraine. It is the generalization of electronic registers that will enable the effective management decisionmaking.

Researchers in the field of public administration, as well as in the legal, economic and environmental sciences, devote their work to the study of e-governanceand theintroduction of environmental management in Ukraine. Among the authors the following ones are worthy of attention: V. Andreev, G. Balyuk, L. Gapeyev, A. Hetman, V. Gorbulin, N. Gritsyak, A. I. Semenchenko, O. Karpenko, I. Klimenko, Y. Kovaleva, Y. Kozachenko, Y. Nesteryak, O. Poprotsky, Y. Shemshuchenko and others.

D. Bell, A. Toffler, K. Hill, G. Kaletnik, S. Kolyadenko, V. Kuybida, I. Ushalenko, O. Kachny, L. Gapeev, O. Balakhonova, V. Birkovich and many others have investigated influence of information and communication technologies on public administration and its economy in their works. In addition, the implementation of national strategies of introduction information and communication technologies in public administration is disclosed in the following official documents:

The Law of Ukraine of January 9, 2007 "On the Fundamental Principles of Information Society Development in Ukraine for 2007-2015"; Decree of the President of Ukraine No. 5 dated January 12, 2015 "On the Strategy for Sustainable Development "Ukraine-2020"; Ordinance of the Cabinet of Ministers of Ukraine No. 275 dated April 3, 2017, "On approval of the Mid-term Plan of Priority Actions of the Government until 2020 and the Plan of Priority Actions of the Government"; the Concept of e-governance in Ukraine, approved by the Cabinet of Ministers of Ukraine No. 678-p dated September 20, 2017.

\section{Information technologies in the system of public administration of Ukraine}

The system of public administration of Ukraine does not meet the needs of the country in carrying out complex reforms in different spheres of public policy and its European choice, as well as European standards of relevant governance. Ukraine ranks low in global government-related competitiveness ratings. According to the World Economic Forum's Global Competitiveness Index (2015), Ukraine ranks 130th (among 144 countries) in the Government Efficiency category, 103rd in the Transparency of Public Policy Formation (Koliadenko, 2016).

The current challenges of society, such as globalization, the rapid change in demand and technology, the depletion of natural resources, environmental pollution, and the food problem, require decisive action to secure national interests and, consequently, Ukraine's national security. Ensuring economic security as a factor of stabilization and development of the domestic economy occupies a prominent place in the formation of national security of the country. Therefore, in the current unstable conditions, when some financial crises change others, ensuring the stability of the domestic economy is an important and urgent task of scientific research (Kaletnik, Pchelianska, 2014).

According to the Law of Ukraine "On Settlements Improvement", subjects in the sphere of settlement improvement are the bodies of state power and bodies of local self-government, enterprises, institutions, organizations, bodies of selforganization of the population, citizens (the Law of Ukrain, 2005).

According to the Law, "settlement improvement" is a complex of works on engineering protection, clearing, drainage and landscaping of the territory, as well as socio-economic, organizational and legal and environmental measures for improvement of microclimate, sanitary cleaning, noise reduction and other on the territory of the settlement for its rational use, proper maintenance and protection, creation of conditions for protection and restoration of the environment favorable for human life (the Law of Ukrain, 2005).

Modern municipal improvement of settlements shall meet a wide range of requirements and factors, among which the most determinative ones are the organizational and legal factors (Figure 1) (Ignatenko, 2016). 
Requirements and factors for modern municipal improvement of settlements

\begin{tabular}{|c|c|c|c|}
\hline socio-cultural \\
economic \\
sanitary and hygienic \\
engineering \\
organizational and legal \\
\hline
\end{tabular}

Figure 1. Requirements and factors for modern municipal improvement

Source: developed by the author on the basis of (Ignatenko, 2016)

The powers of the executive bodies of village, settlement and city councils are as follows (the Law of Ukrain, 2005): ensuring implementation of local programs and taking measures to improve settlements; organization of cleanliness and order control in the territory of the settlement, observance of silence in public places; organization of recreation places for the population; approval of sanitation schemes of settlements and introduction of separate collection of household waste systems; self-government control over the state of improvement and maintenance of settlement territories, engineering structures and objects, enterprises, institutions and organizations, vehicle parking boxes (concerning payment of services for use of fee-paying vehicle parking boxes), landscaping of such territories, protection of green spaces, water bodies etc.; determination of vehicle parking places and parking areas at landscaping facilities; determination of work schedules for outdoor lighting of the territory identifying public toilets on landscaping facilities; attraction of financial and material and technical resources of legal entities and individuals for taking measures for the settlement improvement on contractual basis; determining the share of participation of commercial, household, socio-cultural or other purpose temporary buildings owners in their improvement; determination of the amount of compensation for legal and natural persons for environmental pollution and other environmental damages caused by violation of legislation in the field of public works and environmental protection according to the established procedure; informing the population about taking measures to improve the settlements; participation in holding the annual
all-Ukrainian competition "Settlement of the best improvement and maintenance of public order"; issuance of permission for violation of the objects of improvement in the cases and the procedure provided by this Law.

The sphere of settlement improvement as a system may be divided into such subsystems of the local economy, which at the same time can act as spheres for appropriate state regulation: the street-road network support, external illumination of territories, landscaping of territories, municipal services of territories, engineering protection of territories, building surrounding ground support, other territories within the settlement boundaries support (Ignatenko, 2016).

Considering that it is the responsibility of the state to ensure environmental safety and maintain the ecological balance related to the maintenance of green spaces, engineering protection of territories, waste management, functional status of territories, etc., it is necessary to formulate and implement a unified state policy in this field.

Landscaping subsystems include the following: parks, recreational areas, gardens, squares and grounds, as well as cultural and historical heritage sites, squares, avenues, boulevards, beaches. The subsystem is a collection of landscaped territories of different functionalities, integrated into an interconnected system of settlement infrastructure. Green plantations of settlements effectively fulfill their purpose of forming aesthetics of settlements improvement, protection of water sources and hills from erosion, wind and noise protection, fight against air pollution, the formation of the most comfortable working, life and rest conditions of the population. The 
system of settlement landscaping is characterized by great complexity, which is connected with the complexity of processes occurring in settlements in conditions of active interaction of anthropogenic and natural environment, close dependence on the processes of settlements development, reduction of the area of greenery territories with expansion of development, variety of functions and types of green spaces forming the landscaping system, etc. The landscaping makes it possible to emphasize the structural properties of architectural compositions, it is a wonderful foundation for small forms of landscape sculptures, and is also used as a hedge, dividing strips and security islands (Koliadenko, 2016).

Landscaping in settlements is an essential component and takes up considerable place. Green areas with their participation in the formation of the urban environment are multifunctional, performing, in addition to architectural and planning and aesthetic functions, also sanitary, engineering, protective and recreational ones. Aesthetic qualities of green spaces are a source of spiritual enrichment of a person, reduce psychological tension, improve the visual properties of the city. Lack of green spaces in the city can lead to poor overall health of people.

With relation to the requirements of zoning and city master plans for the creation of a single urban and suburban natural space, suburban green areas with their forest park belts, which are closely related to urban suburbs, are of great importance. As a result, the role and importance of the city's master plans, which should reflect the integrity and unity of the landscaping system, allocate reserve spaces, in order not to allow ever-growing industrial and residential buildings to occupy green spaces, is growing. The plan should stand for preserving and protecting existing plantations. In case of rational land use, it would be possible to create aesthetically attractive and functional green space for years to come (Shvets, Kalinichenko \& Kudlaienko, 2013).

\section{Problems of innovations in the state system}

Now, the reason for inefficient management in many enterprises of Ukraine is the insufficient use of information technologies. Despite the active support of this sector by the state, the problems of studying and speeding up information flows, development and implementation of information and software systems for automation of management, lack of vision of the prospect of IT implementation in executives and, consequently, reduction of management mobility, etc. are not fully resolved (Volontyr, Pavliuk, 2017).

The effectiveness of managing the territories of settlements depends to a great extent on the completeness and reliability of the initial information used in making decisions on its strategic and operational development. The required information is measured by thousands of indicators that characterize the quantitative and qualitative state of the environment elements of the settlement and are collected, accumulated and processed by various branch bodies of state and local authorities (Koliadenko, 2016).

GPS navigation to improve the control system in the area of settlement improvement; online video control with information storage; aerial photography with software and analytical software for state control; terrestrial mobile means of gathering and processing information to monitor the quality of construction, repair and maintenance of streets and roads; automation of regulated processes in the sphere of settlement improvement; fixation of data in the provision of regulated services in the field of settlement improvement (Ignatenko, 2016).

\section{The situation and problems in the field of landscaping by the example of Vinnytsia}

With the growth of the city, with the development of its industry, the problem of environmental protection is becoming more and more complex. Every year, the amount of trees in cities becomes smaller and their condition is not always satisfactory. On most streets, trees were planted in the late 1960s and 1970s, and then the green stock was hardly updated. Landscaping is an integral part of the overall set of municipal improvement activities. Moreover, green spaces affect the formation of the microclimate in the city, contribute to the improvement of sanitary and hygienic living conditions and recreation of residents, as well as the formation of the architectural appearance of the city.

For most cities, the landscaping system has been historically developed and shall be maintained and supported. The level of landscaping of the industrial territory of the building must be at least $40 \%$, and within the territory of the residential area it must be not less than $25 \%$ (including the total area of the greened area of the residential district).

Vinnytsia's green space is approximately 3640.8 hectares, 971.8 hectares of which are of 
general use, and the greening ratio of the city is 53\% at the rate of $40 \% .98 .78 \mathrm{~m}^{2}$ of green space accounts per inhabitant of the city.

The green zone of the city is represented by: - green areas of public use (parks, squares, boulevards, gardens, embankments, plantations on slopes and other ones with free access to recreation);

- green spaces of limited use (planting in the territories of residential buildings, educational institutions, children's institutions, health care facilities, enterprises, etc.);

- green plantations of special purpose (planting of streets, cemeteries, areas of sanitary protection strips, water protection areas, anti-erosion areas, roadside ones).

Some green area objects have a wildlife sanctuary status of national or local importance. Vinnytsia Nature Reserve Fund has thirteen facilities with a total area of 178.97 hectares.

Green areas of public use are important in shaping the urban landscape as well as the entire landscaping system. The city Master Plan proposes to increase the area of green spaces for public use in the nearest time taking into account the formation of a single network along the main watercourses and ponds by 222.9 hectares.

Since 2008 till now, due to the lack of free land for construction in the city, about 9.5 hectares of perspective green areas have been transferred to the category of residential development.

Vinnytsia will become a rather uncomfortable city without the trees, so that this does not happen, it is necessary to take urgent measures. The first step should be to take inventory of the existing fund and assess its condition. To date, the inventory and certification of green space are carried out on paper, no one has the opportunity to use the results of this work, so there is no ability to analyze data.

Themechanismsfordetermining thereproduction cost during the protection and maintenance of green spaces is regulated by Art. 28 of the Law of Ukraine "On settlements improvement" (the Law of Ukrain, 2005).

Removal of trees, shrubs, lawns and flower beds is carried out according to the procedure approved by the Resolution of the Cabinet of Ministers of Ukraine No. 1045 dated August 10, 2006, (the Law of Ukrain, 2005), by decision of the executive body of the village, settlement, city council based on an assignment or according to Art. 34 of the Law of Ukraine "On Regulation of Urban Planning
Activity". During construction, the amount of reproduction cost of the removed green space is reduced by the amount stipulated in the project documentation for landscaping.

The reproduction cost of green space is determined by the methodology approved by the Ministry of Agriculture and Communal Services of Ukraine dated May 12, 2009 No. 127, which was registered at the Ministry of Justice of Ukraine on June 19, 2009, under No. 549/16565. The methodology establishes a mechanism for determining the restorative value of green spaces (trees, shrubs, lawns, flower beds) in settlements, to be paid in the event of removal of green spaces or their loss due to the allotment of land according to the established procedure to a legal or natural person.

The reproduction cost of communal property green spaces is paid to the appropriate local budget.

According to the Methodology, the reproduction cost of green spaces is determined by taking into account the costs of creating and maintaining them up to the age of removal, using some coefficients that provide differentiation of costs depending on the location of green spaces within the settlement, their quality status and other indicators.

However, the cost of supporting green space during the year is determined based on economically justified planned costs for the execution of works on their annual maintenance in accordance with the scheduled maintenance task card, but the methodology does not provide a mechanism for drawing up such scheduled maintenance task card, which leads to the emergence of a corruptogenic factor in this regard and many times increase of the amount of the reproduction cost.

Besides, there is a need to carry out a rather complicated calculation of economically justified planned expenditures for the annual maintenance of green spaces.

Also, the cost of maintaining trees and shrubs is determined by their age. The methodology stipulates that the age of a tree or shrub is determined by the commission without taking into account the two-year rooting period and the inventory of the green space, if any. However, the inventory data of green spaces for many settlements are not updated or not available annually, and the actual age of a tree or shrub is determined by methods that require some time, the availability of special equipment, and the involvement of specialists with appropriate qualifications. Thus, the actual age of a tree or shrub in the absence of inventory data of green space and 
the cost of maintaining a unit of green space during the year is practically impossible to determine.

In reference with the above, it is necessary to change the approaches to determining the reproduction cost of green spaces in settlements using new and simplified mechanisms and using fewer parameters and the possibility of involving lower-skilled specialists to carry out such calculations.

This can be achieved by establishing simplified approaches while determining the reproduction cost of green spaces, which should be a cost estimate of the maintenance work carried out between the time of creation and the time of their removal or loss. Also, to ensure matching of the amount of the compensatory cost for maintaining green space and inflationary processes in the economy, it is necessary to provide the mechanism for applying indexation rate in the calculations of the compensatory cost of keeping trees and shrubs (Volontyr, Pavliuk, 2017).

In addition, in relation to state control of the wrongful damage or destruction of green spaces by offenders, the compensation shall be paid in accordance with calculations of the amount for damage caused to green planting within cities and other settlements approved by the Resolution of the Cabinet of Ministers of Ukraine No. 559 dated April 08, 1999. Penalty payment shall provide the compensation of predetermined extent of damage to the state. According to this Resolution, the extent of damage multiplicity shall be established for each tree, every shrub, lawn and flowerbed which were destroyed or damaged to the degree of termination or, accordingly, to the degree of non-termination of growth. Compensatory cost for keeping shrubs are established for one wild shrub or for each shrub planted in a hedge and a border without taking into account their age and geometric characteristics according to similar indicators.

The approaches to determining the reproduction cost of green space as part of the existing mechanism for removing trees, shrubs, lawns and flower beds should be further improved when granting the vegetation plantation removal permit and the certificate of inspection of vegetation plantation to be removed. This is especially important for implementing the concept of sustainable development, which is identified as a priority in modern Ukraine.

Therefore, it is necessary to amend the Order of the Ministry of Housing and Communal Services of Ukraine No. 127 dated May 12, 2009, registered at the Ministry of Justice of Ukraine on June 19,2009, No. 549/16565, which approved the Methodology for determining the reproduction cost of green spaces.

According to these amendments, the existing approaches to determining the reproduction cost of green spaces in settlements should be improved using simplified mechanisms and using fewer parameters and the possibility of involving lowerskilled specialists to carry out the above calculation.

Particular emphasis should also be placed on the need to inform people about the efficiency and cost savings due to trees and their proper planting.

Trees not only improve air quality, but they also help us store energy, heat in winter and cool the air in summer, which means we can reduce our heating and air conditioning bills.

In winter, trees act as buffers against the icy wind. Winds are the main cause of heat loss in buildings. By planting trees in the right places near homes and other structures, you can reduce heat loss while saving energy.

In the summer, trees have the opposite effect of cooling. Again, they have the effect of buffering the wind, but this time the trees protect the building from the warm air. Often large electricity bills are received in the summer months due to the air conditioner being overloaded so that a building have the needed temperature. With little planning, people can place trees in strategic places where they will eventually reduce the amount of money spent on energy. Branches and leaves, especially when evergreen trees are planted in rows on the north side of the house, can block cold, winter winds, which increases heating costs.

Eventually, the leaves of the trees act as miniconditioners, evaporating moisture from their surfaces and absorbing heat in the process of breathing. According to the New York Forestry, evaporation of moisture through one large tree can have the same effect as 10 air conditioners on 10 rooms that work throughout the day.

To maximize the benefits of tree planting, the following tree planting strategies are offered:

Broad-leaved trees should be planted to the east, south and west of the structure. The shade from these trees will block sunlight during the summer months, but they will allow the sun to penetrate in the winter months when sun ray heat can be beneficial. They shoud be planted at least 7 meters away from the construction to provide enough space for growing. 
Alarge shrub or tree should be planted near an air conditioning device to the south or west, at least 10 meters away. Shading the device from direct sunlight will reduce the amount of energy used to cool the building.

Trees and plants near the driveways where cars are parked are needed to reduce the interior temperature of the cabin, reduce the amount of fuel needed to cool the car.

Winter winds typically force through the door and window frames and increase the demand for the heater to maintain a comfortable indoor temperature. Evergreen trees (trees that hold their leaves or needles in winter) are the best candidates for a live screen outside the building. By planting a wall of evergreens of varying mature height on the north side of the building, some of winter winds can be diverted, resulting in reduced utility bills due to reduced heating costs (Gapiiev, 2018).

The urban environment is changing dynamically, structures are being built, roads are being renovated, new parks are laid out, there are hundreds of thousands of trees in the city, old trees are reaching the age limit, new trees are being planted. The project is needed to enable the residents of Vinnytsia to take part in the life of the trees directly.

Information and communication technologies in the public administration of Ukraine are the basis for improving management and control, efficiency, productivity, economic growth, job creation, reform and an example for the country of how to use the benefits of the "digital" world that will stimulate the development of an open information society as a one of the essential factors for the development of democracy in Ukraine, as well as improving the quality of life of Ukrainian citizens.

\section{Conclusions}

Based on the study of theoretical, methodological and applied aspects of incresing the efficiency of management and control in the sphere of improvement with the use of information technologies aimed at ensuring sustainable local development and creating favorable conditions for human life, it is advisable to draw the following conclusions.

1.The areas ofresearch for improving the efficiency of management and control are determined based on the analysis of information and communication technologies in the management of local authorities and the experience of foreign countries in the sphere of urban improvement.

2. As a result of the research, it is determined that the use of information technologies in public administration contributes to the formation of an open democratic society, which will guarantee respect for the constitutional rights of citizens, to participate in public life, to make appropriate decisions by public authorities and local governments.

3. The use of e-government tools will significantly improve the quality of service to individuals and legal entities and increase the openness, transparency and efficiency of the activity of state and local governments.

\section{References:}

Gapiiev, L. Elektronne uriaduvannia: problemy, priorytety, zavdannia [Electronic governance: problems, priorities, tasks]. Retrieved from: https://i.factor.ua/ukr/journals/ds/2018/march/issue3/ article34920.html (accessed March 12, 2020).

Koliadenko, S. V. (2016). Cyfrova ekonomika: peredumovy ta etapy stanovlennia v Ukraini i u sviti [The digital economy: preconditions and stages of formation in Ukraine and in the world]. Ekonomika. Finansy. Menedzhment, no. 6, pp. 106-107.

Kaletnik, G. M., \& Pchelianska, G. O. (2014). Misce i roli prodovolchoi bezpeky u formuvanniu ekonomichnoi bezpeky Ukrajiny [The place and role of food security in shaping Ukraine's economic security]. Biznes Inform, no. 2, pp. 30-34.

Pro blagoustrii naselenyh punktiv (2005) [On the improvement of settlements] Zakon Ukrainy vid 06 veresnia 2005 roku \# 2807-IV. Vidom. Verkhov. Rady Ukrainy. No 49.2580 p.

Ignatenko, O. P. (2016). Derzhavne reghuliuvannia sfery blaghoustroiu naselenyh punktiv [State regulation of the sphere of settlements improvement]. Kyiv.

Shvets, V. V., Kalinichenko, V. S., \& Kudlaienko, O. O. (2013). Analiz ta vdoskonalennja zelenogho karkasa mista na prykladi $\mathrm{m}$. Vinnyci [Analysis and improvement of the green frame of the city on the example of Vinnytsia]. Suchasni tekhnologhii, materialy i konstrukcii $v$ budivnyctvi.

Volontyr, L. O., \& Pavliuk, T. M. (2017). Vprovadzhennia informaciinyh tekhnologhii na pidpryjemstvi [Implementation of information technologies at the enterprise] Materialy VIII Mizhnarodnoi naukovometodychnoi konferentsii Forum molodyh ekonomistiv-kibernetykiv "Modeliuvannia ekonomiky: 
Vol. 1, No. 1, 2020

problemy, tendentsii, dosvid". Retrieved from: http://elartu.tntu.edu.ua/bitstream/lib/23408/2/ MNK-ME_2017_Volontur_Lmplementation_of_information_110-112.pdf (accessed March 12, 2020).

Yak dereva dopomagaiut u zberezhenni energii? [How trees help conserve energy]. Retrieved from: https://treespleasehamilton.org/2017/01/04/how-do-trees-help-with-energy-conservation (accessed March 12, 2020).

Zelenaia strategiia dlia Odessy: obrezat, posadyt ili poshchitat? (2017) [Green strategy for Odessa: to trim, plant or count?]. Retrieved from: http://forshmag.me/2017/06/27/zelenaya-strategiya-dlyaodessy-obrezat-posadit-ili-poshchitat/ (accessed March 12, 2020).

Gapiiev, L. (2018). Elektronne uriaduvannia: problemy, priorytety, zavdannia [E-Governance: Problems, Priorities, Tasks]. Retrieved from: https://i.factor.ua/ukr/journals/ds/2018/march/issue3/ article34920.html (accessed March 12, 2020). 